\title{
Optimization of Coagulation Parameters forTurbidity Removal Using Box-Behnken model
}

\author{
Khedidja Benouis ${ }^{1, *}$ Ahmed Alami ${ }^{2}$ Yassine Khalfi ${ }^{1}$ \\ Soufiane Guella ${ }^{1}$, Yasmina Khane $e^{3,4}$ \\ ${ }^{1}$ Laboratory of Process Engineering, Materials and Environment, faculty of Technology, University of \\ Djillali Liabes, PO Box 89, Sidi Bel Abbes 22000 -Algeria. \\ ${ }^{2}$ Faculty of Electrical Engineering, University of Djillali Liabes, PO Box 89, Sidi Bel Abbes 22000-Algeria. \\ ${ }^{3}$ Université de Ghardaia, B.P 455, Ghardaïa, Algerie \\ ${ }^{4}$ Laboratory of Applied Chemistry, ACTR Univ Ain Temouchent, PO Box 284, Ain Temouchent $46000-$ \\ Algeria. \\ ${ }^{*}$ Corresponding author. Email: benouis_khadidja@yahoo.fr
}

\begin{abstract}
This study aims to determine the efficacy of using calcium hydroxide $\mathrm{Ca}(\mathrm{OH}) 2$ in coagulation process to treat urban liquid effluent from wastewater purification plant. The response surface methodology was used. The effects and interactions between three key process parameters was enhanced applying Box-Behnken design. Factors studied were: coagulant dosage $(\mathrm{g} / \mathrm{L})$, coagulation speed $(\mathrm{rpm})$, and coagulation time (min). The treatment efficiency was determined by the turbidity removal rate and the final $\mathrm{pH}$ of the treated wastewater. The statistical soundness of the generated model was determined using analysis of variance. The optimal model for determining the relationship between the variables is a second-order quadratic model (R2>98\%). The best turbidity reduction $(91.3 \%)$ was obtained using a $0.50 \mathrm{~g} / \mathrm{L} \mathrm{Ca}(\mathrm{OH}) 2$ coagulant and $130.1 \mathrm{rpm}$ for 5 minutes. Under these conditions, the ultimate $\mathrm{pH}$ of the effluent reached 8 .
\end{abstract}

Keywords: Process, Coagulation, Optimization, Response Surface Methodology, Box-Behnken.

\section{INTRODUCTION}

The optimization of water treatment processes is of great importance because it improves efficiency and reduces the cost of treatment $[1,2]$. One of the more modern methodologies for process optimization is Response Surface Methodology (RSM). It involves the design of experiments, analysis, and partial regressionfit modeling of experimental parameters $[3,4]$. The approach may combine multiple factors at once and reveal reciprocal interactions in a process' yield; it also minimizes the number of experimental tests necessary to achieve statistically acceptable results.

The current study adjusted the process variables previously known to affect the water coagulation process $[5,6]$. RSM was used to assess the impacts of three variables (Lime dosage, coagulation speed, and coagulation time) and their effects on turbidity removal and the final $\mathrm{pH}$ of wastewater treated in order to eliminate the colloidal suspended matter responsible for the turbidity of the water and to achieve a final $\mathrm{pH}$ inthe range of $6-8$ to avoid a post-adjustment of $\mathrm{pH}$ due to the use of calcium hydroxide.

\subsection{Related works and contributions}

The RSM methodology is one of the more recent ways of multiple response optimizations that is being applied in industries. It is commonly used because to its low cost and low test requirement. RMS has been used to optimize different processes for wastewater treatment.

Khettaf et al. [7] used the coagulation-flocculation process to remove organic matter from surface water used for drinking water production. The variables influencing the responses are the initial $\mathrm{pH}$ of the water and the concentrations of coagulant and flocculant used.RSM results reveal that the optimal conditions were an initial $\mathrm{pH}$ of 6.9 , using $0.133 \mathrm{~g} / \mathrm{L}$ 
and $0.06 \mathrm{~g} / \mathrm{L}$ of coagulant and flocculant, respectively. The final $\mathrm{pH}$ obtained was 6.78 and the abatment reached $56 \%$ and $59 \%$ in terms of COD and UV-254 respectively.

In another work by Louhıchı et al. [8], similar to Khettaf et al. [7], the wastewater from the vegetable oil refinery was also treated by coagulation-flocculation. This study also used RSM but Box-Behnken (BBD) as an optimization design. The same variable factors were adopted. The optimum was acquired at an initial $\mathrm{pH}$ of 9.23 using 2400 $\mathrm{mg} / \mathrm{L}$ and $60.05 \mathrm{mg} / \mathrm{L}$ of coagulant and flocculant, respectively. The treatment eliminated $99 \%$ of the
COD and $100 \%$ of the turbidity.

Gökçek, et al. [9] optimized the coagulation process for COD, SS, and turbidity removal from slaughterhouse wastewater. The Box Behnken designwas used. The various experimental factors were the alum coagulant dosage, the coagulation speed and the settling time. Optimization gave maximum removal $(75,90$, and $91 \%)$, respectively using $1 \mathrm{~g} / \mathrm{L}$ of alum, stirring at a speed of $150 \mathrm{rpm}$ and allowing the sample to settle for 10 minutes. RSM has also been used in other studies to optimize wastewater treatment process. Table 1 presents an overview of the work carried out above.

Table 1. Overview of water and wastewater treatment studies carried out with RSM

\begin{tabular}{|c|c|c|c|c|c|c|}
\hline $\begin{array}{l}\text { Type of } \\
\text { wastewater }\end{array}$ & Process & Design & Runs & Variables & responses & Reference \\
\hline Surface water & \multirow{4}{*}{$\begin{array}{l}\text { Coagula } \\
\text { tion } \\
\text { Floccula } \\
\text { tion }\end{array}$} & CCD & 29 & $\begin{array}{l}\mathrm{X} 1=\text { coagulant concentration } \\
\mathrm{X} 2=\text { flocculant concentration } \\
\mathrm{X} 3=\text { initial } \mathrm{pH}\end{array}$ & $\begin{array}{l}\mathrm{Y} 1=\mathrm{COD} \text { removal } \\
\mathrm{Y} 2=\text { absorbance } \\
\mathrm{Y} 3=\text { final } \mathrm{pH}\end{array}$ & [7] \\
\hline \begin{tabular}{|l} 
Vegetable- \\
oil \\
refinery \\
wastewater \\
\end{tabular} & & $\begin{array}{l}\text { Box } \\
\text { Behnken }\end{array}$ & 29 & $\begin{array}{l}X 1=\text { coagulant concentration } \\
\text { X2 = flocculant concentration } \\
\text { X3 = initial } \mathrm{pH}\end{array}$ & $\begin{array}{l}Y 1=\text { turbidity removal } \\
Y 2=C O D \text { removal }\end{array}$ & [8] \\
\hline $\begin{array}{l}\text { Slaughterhou } \\
\text { sewastewater }\end{array}$ & & $\begin{array}{c}\text { Box } \\
\text { Behnken }\end{array}$ & 28 & $\begin{array}{l}X 1=\text { Coagulant concentration } \\
X 2=\text { coagulation speed } \\
X 3=\text { Settling time }\end{array}$ & $\begin{array}{l}Y 1=\text { COD removal } \\
Y 2=S S \text { removal } \\
Y 3=\text { Turbidity removal }\end{array}$ & [9] \\
\hline $\begin{array}{l}\text { Petroleum } \\
\text { wastewater }\end{array}$ & & CCD & 13 & $\begin{array}{l}\mathrm{X} 1=\text { initial } \mathrm{pH} \\
\mathrm{X}_{2}=\text { coagulant concentration }\end{array}$ & $\begin{array}{l}\mathrm{y} 1=\text { final } \mathrm{pH} \\
\mathrm{Y} 2=\mathrm{COD} \text { removal } \\
\mathrm{Y} 3=\text { turbidity removal } \\
\mathrm{Y} 4=\mathrm{TDS} \text { removal } \\
\mathrm{Y} 5=\text { color removal }\end{array}$ & [10] \\
\hline $\begin{array}{l}\text { Palm oil mill } \\
\text { wastewater }\end{array}$ & \multirow{2}{*}{$\begin{array}{l}\text { Electro- } \\
\text { Coagula } \\
\text { tion }\end{array}$} & $\begin{array}{c}\text { Box } \\
\text { Behnken }\end{array}$ & 16 & $\begin{array}{l}X 1=\text { time } \\
X 2=\text { Voltage } \\
X 3=\mathrm{NaCl} \\
\text { concentration }\end{array}$ & $\begin{array}{l}Y 1=\text { COD removal } \\
Y 2=T S S \text { removal } \\
Y 3=T D S \text { removal }\end{array}$ & [11] \\
\hline $\begin{array}{l}\text { Pharmaceut } \\
\text { ical } \\
\text { wastewat } \\
\text { er }\end{array}$ & & CCD & 30 & $\begin{array}{l}\mathrm{x} 1=\text { initial } \mathrm{pH} \\
\times 2=\text { Cefazolin concentration } \\
\times 3=\text { Currentdensity } \\
\mathrm{x} 4=\text { Electrolysis time }\end{array}$ & Y1 = Cefazolin removal & [12] \\
\hline
\end{tabular}

\section{METHODOLOGY}

\subsection{Origin And Characteristic of The Effluent}

The studied effluent was sampled from the wastewater purification plant, located in the town of Sidi Bel Abbes (western Algeria). The effluent was collected from the clarification tank before any chemicaltreatment. The wastewater is characterized by a $\mathrm{pH}$ of 7,5 , a turbidity of $489 \mathrm{NTU}$, and a dissolved salt levelof $1253 \mathrm{~g} / \mathrm{L}$.

\subsection{Coagulation-}

\section{Flocculation Tests And} Experimental Design

Tests of coagulation flocculation were realized in a flocculator device (Jar Test AOUA/UTC). As a coagulant, calcium hydroxide $\mathrm{Ca}(\mathrm{OH})_{2}$ was used. The volume of wastewater used is $400 \mathrm{~mL}$ per test. 
To optimize the variables that affect the efficiency ofthe coagulation process, RSM was employed. The statistical software Design Expert 13.0 was utilized for the experiment design and data analysis. The Box- Behnken (BBD) design was used to optimize the turbidity removal and the final $\mathrm{pH}$ of the wastewater treated by coagulation method.

Three factors were varied: coagulant dosage (A), coagulation speed (B), and coagulation time (C). The coded levels and ranges of each factor are shown in Table 2. The responses of the design were: the turbidity removal (Y1) and the final pH (Y2). 15 experimental runs were performed.

Table 2. Experimental and coded values

\begin{tabular}{|c|c|c|c|c|}
\hline Factors & Symbol & \multicolumn{4}{|c|}{ Coded levels } \\
\cline { 3 - 5 } $\begin{array}{c}\text { coagulant } \\
\text { dosage } \\
\text { (g/L) }\end{array}$ & A & 0.5 & 2 & 3.5 \\
\hline $\begin{array}{c}\text { Coagulation } \\
\text { speed } \\
\text { (rpm) }\end{array}$ & B & 100 & 150 & 200 \\
\hline $\begin{array}{c}\text { Coagulation } \\
\text { time (min) }\end{array}$ & C & 3 & 5 & 7 \\
\hline
\end{tabular}

The model's fitness was assessed using a significance test and an analysis of variance. A quadratic equation model, expressed in Equation (1), was used to optimize the coagulation process.

$$
\mathrm{Y}=\beta_{0}+\sum_{\mathrm{i}=1}^{\mathrm{k}} \beta_{\mathrm{i}} \mathrm{X}_{\mathrm{i}}+\sum_{\mathrm{i}=1}^{\mathrm{k}} \beta_{\mathrm{i}} \mathrm{X}_{\mathrm{i}}^{2}+\sum_{\mathrm{i}=1 \mathrm{j}=2}^{\mathrm{k}-1} \sum_{\mathrm{j}=2}^{\mathrm{k}} \beta_{\mathrm{ij}} \mathrm{X}_{\mathrm{i}} \mathrm{X}_{\mathrm{j}}
$$

Where $\mathrm{Y}$ is the response, $\mathrm{X}_{\mathrm{i}}$ represents the input factor, $\beta_{0}$ is the intercept, the linear influence of theinput factor $X_{i}$ is denoted by $\beta i$, -the interaction effect between $X_{i}$ and $X j$ is denoted by $\beta \mathrm{ij}$, the quadratic effectof $\mathrm{Xi}$ is $\beta_{\mathrm{ii}}$.

The turbidity removal efficiency $(\%)$ is calculatedaccording to Equation (2):
Turbidity removal, $(\%)=[(1-$

$\left.\left.\left(\mathrm{T}_{\mathrm{f}}\right) / \mathrm{T}_{\mathrm{i}}\right)\right]^{* 100}$

$\mathrm{T}_{\mathrm{i}}$ is the initial turbidity

(2)

$\mathrm{T}_{\mathrm{f}}$ is the final turbidity

\section{RESULTS AND DISCUSSION}

The relationships between turbidity removal efficiency, the final $\mathrm{pH}$ of treated wastewater, and the factors (coagulant dosage, coagulant speed, and coagulant time) were evaluated. Table 3 shows the operating parameters, results of the experiments that were conducted and predicted data.

\subsection{Analysis Of Variances (ANOVA)}

The results in Table 3 showed that the experimental data fit the model perfectly. Multiple regression analysiswas used to analyze the experimental data. The second order polynomial Equations (3) and (4) were used to relate the responses values and the coded factors. The synergistic effect is indicated by the positive sign in front of the parameters, and the antagonistic effect is indicated by the negative sign.

$$
\begin{aligned}
\mathrm{Y} 1= & 98.4467-0.45375 \mathrm{~A}-1.72125 \mathrm{~B}+1.6275 \mathrm{C} \\
& -1.3475 \mathrm{AB}+2.22 \mathrm{AC}-0.875 \mathrm{BC}-8.69958 \mathrm{~A}^{2} \\
& +6.16042 \mathrm{~B}^{2}-8.06208 \mathrm{C}^{2} \\
\mathrm{Y} 2= & 9.09333+0.93875 \mathrm{~A}+0.6975 \mathrm{~B}-0.38375 \mathrm{C} \\
& +0.7275 \mathrm{AB}-0.33 \mathrm{AC}+0.5375 \mathrm{BC}- \\
& 0.374167 \mathrm{~A}^{2} \\
& +1.37333 \mathrm{~B}^{2}+0.845833 \mathrm{C}^{2}
\end{aligned}
$$

\begin{tabular}{|c|c|c|c|c|c|c|c|}
\hline \multirow{2}{*}{ Test } & \multirow{2}{*}{$\begin{array}{c}\text { A } \\
: \\
\text { coagula } \\
\text { nt } \\
\text { dosage } \\
\text { (g/L) }\end{array}$} & \multirow{2}{*}{$\begin{array}{l}\text { B: } \\
\text { Coagu } \\
\text { lation } \\
\text { speed } \\
\text { (rpm) }\end{array}$} & \multirow{2}{*}{$\begin{array}{c}\text { C: } \\
\text { Coagulation } \\
\text { time (min) }\end{array}$} & \multicolumn{2}{|c|}{$\begin{array}{c}\text { Y1: } \\
\text { Turbidity removal (\%) }\end{array}$} & \multicolumn{2}{|c|}{$\begin{array}{c}\text { Y2: } \\
\text { Final pH }\end{array}$} \\
\hline & & & & $\begin{array}{l}\text { Actual } \\
\text { value }\end{array}$ & $\begin{array}{c}\text { Preditcted } \\
\text { value }\end{array}$ & Actual value & $\begin{array}{c}\text { Preditcted } \\
\text { value }\end{array}$ \\
\hline 1 & 0.5 & 200 & 5 & 96.24 & 95.99 & 96.24 & 95.99 \\
\hline 2 & 0.5 & 150 & 7 & 81.61 & 81.42 & 81.61 & 81.42 \\
\hline 3 & 2 & 200 & 3 & 95.26 & 94.20 & 95.26 & 94.20 \\
\hline 4 & 0.5 & 100 & 5 & 97.86 & 95.99 & 97.86 & 95.99 \\
\hline 5 & 3.5 & 150 & 3 & 77.32 & 77.51 & 77.32 & 77.51 \\
\hline 6 & 3.5 & 100 & 5 & 98.27 & 98.52 & 98.27 & 98.52 \\
\hline 7 & 2 & 150 & 5 & 97.99 & 98.45 & 97.99 & 98.45 \\
\hline
\end{tabular}

For each response, the BBD design gave statistical parameter data. The variance analysis (ANOVA) was used to generate these statistical data, which were then used to determine the optimization's significance.

Table 3. Experimental and predicted data (BBD design) 


\begin{tabular}{|c|c|c|c|c|c|c|c|}
\hline 8 & 2 & 150 & 5 & 98.62 & 98.45 & 98.62 & 98.45 \\
\hline 9 & 3.5 & 200 & 5 & 91.26 & 92.14 & 91.26 & 92.14 \\
\hline 10 & 2 & 100 & 7 & 99.58 & 100.64 & 99.58 & 100.64 \\
\hline 11 & 2 & 200 & 7 & 95.26 & 95.70 & 95.26 & 95.70 \\
\hline 12 & 2 & 150 & 5 & 98.73 & 98.45 & 98.73 & 98.45 \\
\hline 13 & 3.5 & 150 & 7 & 86.52 & 85.20 & 86.52 & 85.20 \\
\hline 14 & 2 & 100 & 3 & 96.08 & 95.64 & 96.08 & 95.64 \\
\hline 15 & 0.5 & 150 & 3 & 81.29 & 82.61 & 81.29 & 82.61 \\
\hline
\end{tabular}

The parameters such as F-value, $\mathrm{P}$-value, $\mathrm{R}^{2}$ and $\mathrm{R}^{2}$ adjusted were determined to assess the model's effectiveness. The Model F-value of 41.59 and 70.05 shown in Tables 4 and 5 suggest that the model is significant. P-values of the model terms less than $5.10^{-2}$ are considered significant and confirm factor-response interactions. Based on this, the factors $\mathrm{B}$ and $\mathrm{C}$ and the interaction terms
$\mathrm{A}^{2}, \mathrm{~B}^{2}$, and $\mathrm{C}^{2}$ had significant individual and quadratic effects on the removal of turbidity. Also, the parameters $\mathrm{A}$ and $\mathrm{C}$ had significant interactive effects between them. Analysis revealed that all three factors had significant individual $(\mathrm{A}, \mathrm{B}, \mathrm{C})$, quadratic $\left(\mathrm{A}^{2}, \mathrm{~B}^{2}, \mathrm{C}^{2}\right)$, and interactive $(\mathrm{AB}, \mathrm{AC}, \mathrm{BC})$ effects on the final $\mathrm{pH}$ value.

Table 4. Fit statistics for the response Y1 (turbidityremoval)

\begin{tabular}{|c|l|l|l|l|l|}
\hline Source & $\begin{array}{l}\text { Sumof } \\
\text { Squares }\end{array}$ & Df & $\begin{array}{l}\text { Mean } \\
\text { Square }\end{array}$ & F-value & p-value \\
\hline Model & 761.13 & 9 & 84.57 & 41.59 & 0.0004 \\
\hline A-Coagulantdosage & 1.65 & 1 & 1.65 & 0.81 & 0.4094 \\
\hline B-Coagulationspeed & 23.70 & 1 & 23.70 & 11.66 & 0.0190 \\
\hline C-Coagulationtime & 21.19 & 1 & 21.19 & 10.42 & 0.0233 \\
\hline AB & 7.26 & 1 & 7.26 & 3.57 & 0.1174 \\
\hline AC & 19.71 & 1 & 19.71 & 9.70 & 0.0264 \\
\hline BC & 3.06 & 1 & 3,06 & 1,51 & 0,2743 \\
\hline $\mathrm{A}^{2}$ & 279.44 & 1 & 279,44 & 137,43 & $<0.0001$ \\
\hline $\mathrm{B}^{2}$ & 140.13 & 1 & 140,13 & 68,92 & 0,0004 \\
\hline $\mathrm{C}^{2}$ & 239.99 & 1 & 239,99 & 118,03 & 0,0001 \\
\hline Lack of Fit & 9.85 & 3 & 3.28 & 20.59 & 0.0467 \\
\hline Pure Error & 0.3189 & 2 & 0.1594 & $/$ & $/$ \\
\hline
\end{tabular}

Table 5. Fit statistics for the response $\mathrm{Y} 2$ (final $\mathrm{pH}$ )

\begin{tabular}{|c|c|c|c|c|c|}
\hline Source & $\begin{array}{c}\text { Sum of } \\
\text { Squares }\end{array}$ & df & $\begin{array}{c}\text { Mean } \\
\text { Square }\end{array}$ & F-value & p-value \\
\hline Model & 25.89 & 9 & 2.88 & 70.05 & 0.0001 \\
\hline $\begin{array}{c}\text { A- } \\
\text { Coagulantdosage }\end{array}$ & 7.05 & 1 & 7.05 & 171.71 & $\begin{array}{c}< \\
0.0001\end{array}$ \\
\hline $\begin{array}{c}\text { B- } \\
\text { Coagulationspeed }\end{array}$ & 3.89 & 1 & 3.89 & 94.79 & 0.0002 \\
\hline $\begin{array}{c}\text { Coagulationtime } \\
\text { C- }\end{array}$ & 1.18 & 1 & 1.18 & 28.69 & 0.0030 \\
\hline AB & 2.12 & 1 & 2.12 & 51.56 & 0,0008 \\
\hline AC & 0.4356 & 1 & 0.4356 & 10.61 & 0.0225 \\
\hline BC & 1.16 & 1 & 1.16 & 28.15 & 0.0032 \\
\hline A & 0.5169 & 1 & 0.5169 & 12.59 & 0.0164 \\
\hline
\end{tabular}




\begin{tabular}{|c|c|c|c|c|c|}
\hline $\mathrm{B}^{2}$ & 6.96 & 1 & 6.96 & 169.61 & $<$ \\
\hline $\mathrm{C}^{2}$ & 2.64 & 1 & 2.64 & 64.34 & 0.0001 \\
\hline Lack of Fit & 0.1832 & 3 & 0.0611 & 5.54 & 0.1568 \\
\hline Pure Error & 0.0221 & 2 & 0.0110 & & \\
\hline
\end{tabular}

Figure 1 shows the relationship between experimental (actual) and predicted model values. We can observe that the predicted values of the model follow the experimental values well because they are near the diagonal axis.
The values of the coefficient of determination $\mathrm{R}^{2}$ of 0.98 and 0.99 (table 6) obtained for the removal of turbidity (Y1) and for the final $\mathrm{pH}$ of wastewater (Y2), respectively, revealed a good fit of themodel.
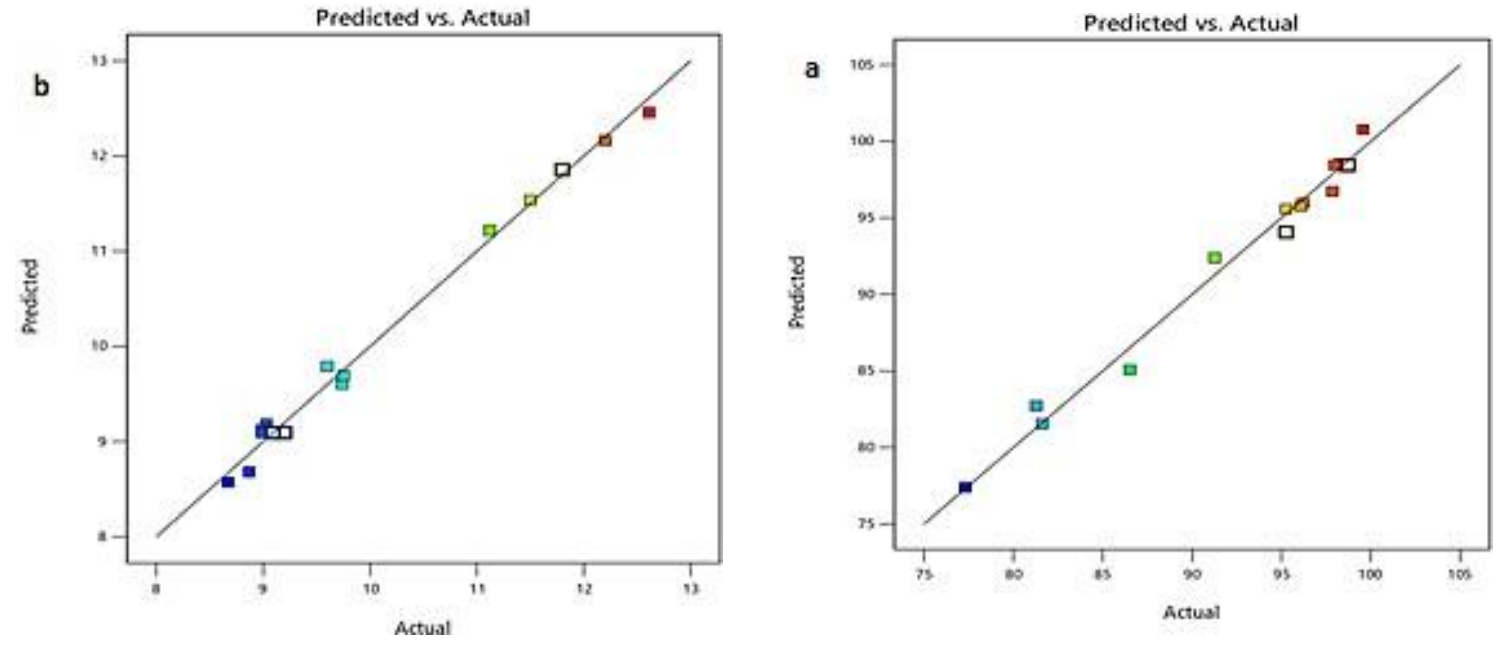

Figure 1 predicted vs. actual values:

(a) of turbidity removal (Y1), (b) of final pH (Y2)

Referring to table 6 , the predicted $\mathrm{R}^{2}$ values for turbidity removal and the final $\mathrm{pH}$ are in the order of 0.7948 and 0.8857 , which is in agreement with the adjusted $\mathrm{R}^{2}$ values of 0.9631 and 0.9780 , respectively. The difference is less than 0.2 , which indicates that the model adopted is significant.

The correct precision value must be greater than 4 . The correct precision values for the rate of turbidity removal and the final $\mathrm{pH}$ are 20.08 and 23.47, respectively. Therefore, both models are accepted.

Table 6. Statistical parameter values

\begin{tabular}{|c|c|c|}
\hline Parameter & Turbidity removal(\%) & Final $\mathrm{pH}$ \\
\hline Standard deviation & 1.43 & 0.2026 \\
\hline Mean & 92.79 & 10.08 \\
\hline $\mathrm{R}^{2}$ & 0.9868 & 0.9921 \\
\hline Adjusted- $\mathrm{R}^{2}$ & 0.9631 & 0.9780 \\
\hline Predicted- $\mathrm{R}^{2}$ & 0.7948 & 0.8857 \\
\hline Adequate precision & 20.0855 & 23.4745 \\
\hline
\end{tabular}

\subsection{Optimization Of Parameters}

To obtain maximum turbidity removal under optimal conditions, an optimization analysis was performed. Theobjectives of this analysis and its limitations are presented in Table 7. Prior to the 
analysis, aims were specified to find the optimized process conditions. The final $\mathrm{pH}$ of the wastewater was chosen to be in range 6 and 8 . It is known that calcium hydroxide in its coagulant form induces very alkaline final $\mathrm{pH}$. So this range was chosen on the basis of obtaining a final $\mathrm{pH}$ of the treated water close to neutral.

Table 7. Objectives and ranges of optimization

\begin{tabular}{|l|c|c|c|}
\hline \multicolumn{1}{|c|}{ Parameter } & Aim & $\begin{array}{c}\text { Minimum } \\
\text { level }\end{array}$ & $\begin{array}{c}\text { Maximum } \\
\text { level }\end{array}$ \\
\hline $\begin{array}{l}\text { A- } \\
\text { Coagulant } \\
\text { dosage }\end{array}$ & Minimum & 0,5 & 3,5 \\
\hline $\begin{array}{l}\text { B- } \\
\text { Coagulation } \\
\text { speed }\end{array}$ & In range & 100 & 200 \\
\hline $\begin{array}{l}\text { C- } \\
\text { Coagulation } \\
\text { time }\end{array}$ & In range & 3 & 7 \\
\hline $\begin{array}{l}\text { Turbidity } \\
\text { removal }\end{array}$ & Maximize & 50 & 100 \\
\hline Final pH & In range & 6 & 8 \\
\hline
\end{tabular}

According to the objectives of the study, the selectedoptimal conditions was, coagulant dosage of $0.5 \mathrm{~g} / \mathrm{L}$, coagulation speed of $130.1 \mathrm{rpm}$ and coagulation time of $5 \mathrm{~min}$. At these optimal conditions, the predicted removal of turbidity was
$91.3 \%$ and the final $\mathrm{pH}$ was of 8 . The desirability of these optimal conditions is 0.908 . The $3 \mathrm{D}$ graph of this desirability is shown in Figure 2.

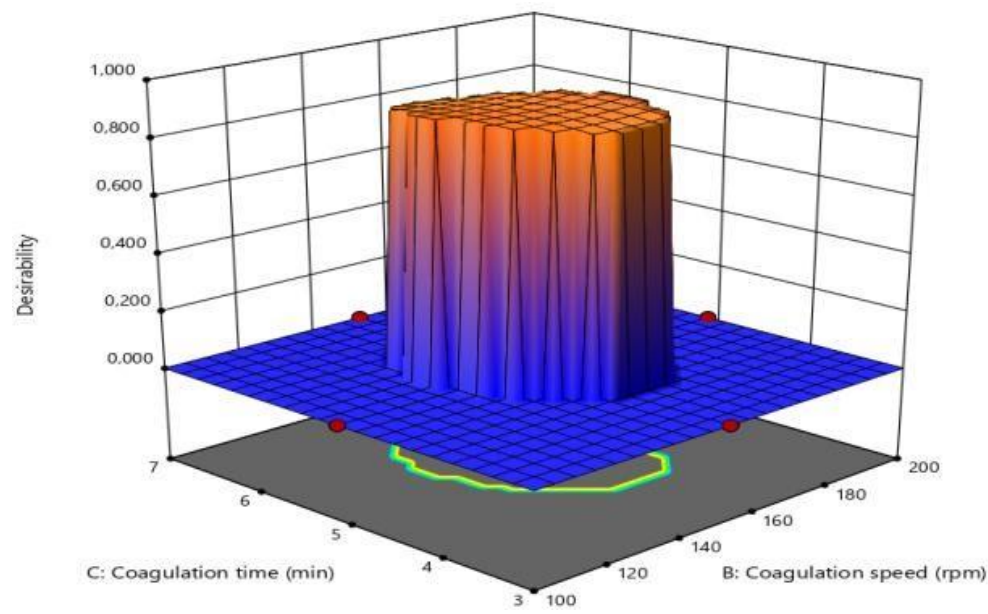

Figure 2 Desirability surface for optimal conditions Figures 3 and 4 show 3D surface diagrams for the turbidity removal and the final $\mathrm{pH}$, respectively, using $0.5 \mathrm{~g}$ of coagulant.

The Figure 3 shows a minor interaction between the agitation speed and the reduction of turbidity; changing its value along its axis has no meaningful effect on the elimination of turbidity in the wastewater. While a considerable interaction between coagulation time and turbidity reduction can be noted in the same figure, a maximum range of elimination is reached between 4 and $6 \mathrm{~min}$. 


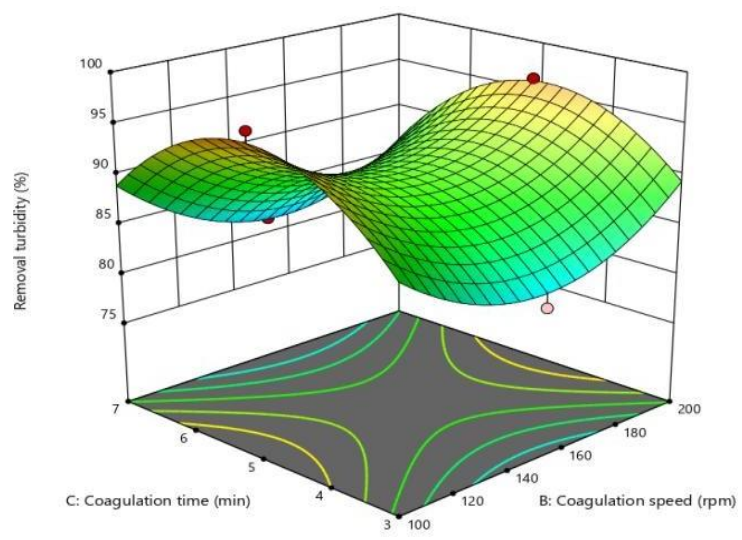

Figure 3 : 3D-surface diagram for the turbidity removal

The Figure 4 shows that the interactions between time or speed of stirring and the final $\mathrm{pH}$ are weak; a change in the value of time or speed of stirring does not significantly affect the variation of the final $\mathrm{pH}$.

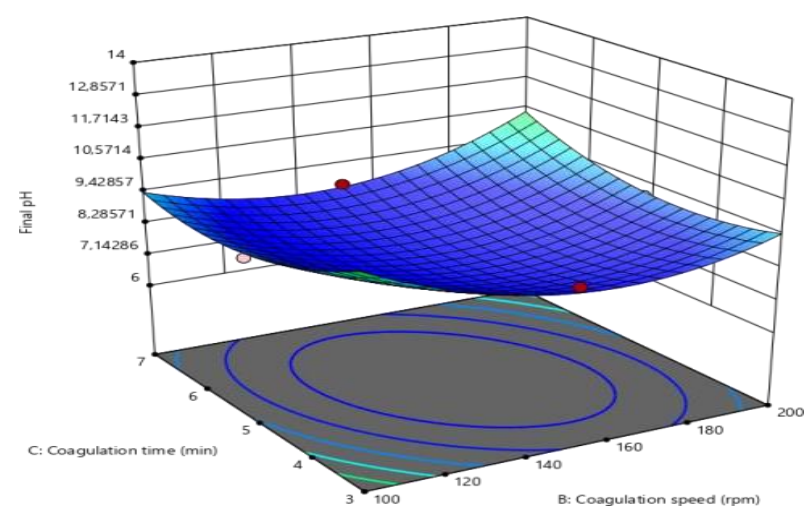

Figure 4 : 3D-surface diagram for the final $\mathrm{pH}$ value

\section{CONCLUSION}

This study aimed at optimizing the operating conditions of the coagulation process applied to the pre- treatment of urban liquid effluent in the wastewater purification plant in the town of Sidi Bel Abbes (Algeria). The Box-Behnken Design was used to assess the effects of coagulant dosage (calcium hydroxide), coagulation speed, and coagulation time on the reduction of turbidity and the final $\mathrm{pH}$ of the wastewater.

The results show that the coagulation speed and time individually influence the reduction of turbidity, while the final $\mathrm{pH}$ value is influenced by all three factors. A second-order mathematical model was found to be well-adjusted to the experimental data.

The optimal conditions obtained were a $\mathrm{Ca}(\mathrm{OH})_{2}$ dosage of $0.5 \mathrm{~g} / \mathrm{L}$ and a coagulation speed of $130.1 \mathrm{~min}$ for a time of 5 minutes. The optimum condition makes it possible to obtain maximum performance from the coagulation process while minimizing the total cost of the treatment.

\section{REFERENCES}

[1] L. Rachidi, G. Kaichouh, M. Khachani, A. Zarrouk, M.El Karbane, H. Chakchak, I Warad,

A. EL Hourch, K. El Kacemi, A. Guessous, Optimization and modeling of the electroFenton process for treatment of sertraline hydrochloride: Mineralization efficiency, energy cost and biodegradability enhancement, Chemical Data Collections, 2021 DOI: https://doi.org/10.1016/j.cdc.2021.100764

[2] S. Rohani, J. Went, D.F. Duvenhage, R. Gerards,

C. Wittwer, T. Fluri, Optimization of water management plans for CSP plants through 
simulation of water consumption and cost of treatment based on operational data, Solar Energy,

2021

DOI:

https://doi.org/10.1016/j.solener.2021.05.044

[3] A. Perec, Multiple Response Optimization of Abrasive Water Jet Cutting Process using Response Surface Methodology (RSM), Procedia

Computer

Science,

2021

DOI:

https://doi.org/10.1016/j.procs.2021.08.096

[4] T. Karchiyappan, R.R. Karri, Chapter 21 Process Optimization and Modeling of Hydraulic Fracturing Process Wastewater Treatment Using Aerobic Mixed Microbial Reactor via Response Surface Methodology, Editor(s): Rama Rao Karri, Gobinath Ravindran, Mohammad Hadi Dehghani, Soft Computing Techniques in Solid Waste and Wastewater Management, Elsevier, 2021, pp. 351-363. DOI:https://doi.org/10.1016/B978-0-12824463-0.00023-9

[5] B. Singh, P. Kumar, Pre-treatment of petroleum refinery wastewater by coagulation and flocculation using mixed coagulant: Optimization of process parameters using response surfacemethodology (RSM), Journal of Water Process

Engineering, 2020

DOI:

https://doi.org/10.1016/j.jwpe.2020.101317

[6] N.M. Huzir, $\quad$ Md M.A. Aziz, S.B. Ismail, N.A.N. Mahmood, N.A. Umor, S. Anuar F.S. Muhammad, Optimization of coagulationflocculation process for the palm oil mill effluent treatment by using rice husk ash, Industrial Crops and Products, 2019 DOI: https://doi.org/10.1016/j.indcrop.2019.111482

[7] S. Khettaf, I. Khouni, G. Louhichi, A. Ghrabi, L. Bousselmi, K.E. Bouhidel, M. Bouhelassa, Optimization of coagulationflocculation process in the treatment of surface water for a maximum dissolved organic matter removal using RSM approach. Water Supply, 2021, pp. 3042-3056. DOI: https://doi.org/10.2166/ws.2021.070

[8] G. Louhıchı, L. Bousselm1, A. Ghrab1, Process optimization via response surface methodology in the physico-chemical treatment of vegetable oil refinery wastewater, Environ Sci Pollut Res, 2019, pp. 18993-19011. DOI https://doi.org/10.1007/s11356-018-2657-Z
[9] Ö.B. Gökçek, S. Özdemir, Optimization of theCoagulation-Flocculation Process forSlaughterhouse Wastewater Using Response Surface Methodology, Clean - Soil, Air, Water, 2020 DOI

https://doi.org/10.1002/clen.202000033

[10]B. Singh and P. Kuma, Pre-treatment of petroleum refinery wastewater by coagulation and flocculation using mixed coagulant: Optimization of process parameters using response surfacemethodology (RSM), Journal of Water

Engineering, Process

DOI:

https://doi.org/10.1016/j.jwpe.2020.101317

[11]M.R. Lubis, D.S. Fujianti1 , R. Zahara, Darmadi, the optimization of the electrocoagulation of palm oil mill effluent with a box-behnken design, International Journal of Technology, 2019, pp.137- 146 DOI: https://doi.org/10.14716/ijtech.v10i1.838

[12] M. Bajpai, S.S. Katoch, A. Kadier, P.C. Ma, Treatment of pharmaceutical wastewater containing cefazolin by electrocoagulation (EC): Optimization of various parameters using response surface methodology (RSM), kinetics and isotherms study, Chemical Engineering Research andDesign, 2021 , DOI:

https://doi.org/10.1016/j.cherd.2021.10.012

\section{NOMENCLATURE}

\begin{tabular}{|c|c|}
\hline $\begin{array}{c}\text { Acron } \\
\text { ym }\end{array}$ & Meaning \\
\hline $\begin{array}{c}\text { ANOV } \\
\text { A }\end{array}$ & Analysis Of Variance \\
\hline UV & Ultra Violet \\
\hline BBD & Box-Behnken Design \\
\hline SS & Suspended Solids \\
\hline RM & Response Surface \\
S & Methodology \\
\hline COD & Chemical Oxygen Demand \\
\hline
\end{tabular}

